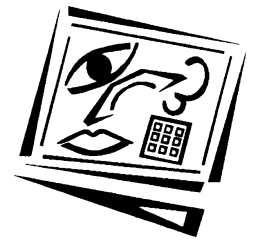

\title{
Learning to play games or playing games to learn? A health education case study with Soweto teenagers
}

\begin{abstract}
Alan Amory
University of Johannesburg

The aim of this study was to investigate the use of an educational computer video game in teaching and learning. Cultural-historical activity theory is used heuristically to explore the social and cultural interactions during game play. It is argued that knowledge construction occurs when video games function as a tool to mediate learning rather than as instructional media. The unit of analysis is not the game as instruction but engagement with the game. Twelve 14 to 19 year old black orphans from Soweto, South Africa, participated in a case study. Groups of three participants, which included both sexes, played the game for at least six hours, kept a personal reflective journal, and after play answered a knowledge test and participated in a round-robin discussion. Results show that participants gained new knowledge, recognised that the game mediated their learning, identified the object of the activity and discussed how they might help their community. Results support the use of games as tools to mediate learning.
\end{abstract}

\section{Introduction}

The problem under investigation in this paper relates to the use of computer video games in teaching and learning. Firstly the potential of computer video games in teaching and learning is briefly explored. Thereafter, learning from and learning with computer games in the classroom are explored. It is then argued that the learning with position, which is congruent with contemporary learning theories associated with social constructivism, offers the most likely theoretical position to support the use of computer video games in the classroom.

\section{Potential of educational computer video games}

Many authors have argued that computer video games could support teaching (Rieber, 1995; Quinn, 2005; Amory, Naicker, Vincent \& Adams, 1999; Gee, 2003), and fostered learning (Rieber, 1996) and cognitive development (Billen, 1993). These ideas were supported by Amory, Naicker, Vincent and Adams (1999) who found that students were motivated to use games as a useful learning tool. Betz (1995) suggested that play could influence the development of visualisation, experimentation and creativity. Games could support the development of communities of practice that include reflective activities, interest, understanding and epistemologies (Shaffer, 2005). However, Prensky (2005) argued that only complex games, and not trivial ones, could support learning, cognitive development, visualisation, experimentation or creativity. Trivial games Prensky (2005) argued include those that are familiar to most adults such as board games (for example, Scrabble, Monopoly, and Mah-Jong) and simple onedimensional, computer-based content games (for example, Carmen Sandiego and Math 
Blaster). These trivial games are easy to complete within an hour or less. Complex games, on the other hand, require players to commit more than 10 hours to identify and negotiate complex relationships between simulated and real characters, solve ever more complex game problems, and understand ethical dilemmas. A number of other games attributes are also thought to be important in the design and use of games in teaching and learning.

Crawford (1982) suggested that games should represent emotional reality in order to support players' fantasy. Rollings and Adams (2003) suggested that game play includes linked problems, puzzles or challenges in a virtual environment. Amory (2007) therefore proposed that educational games should present relevant, explorative, emotive and engaging environments that include complex challenges or puzzles. Smeets (2005) argued that powerful learning environments include rich contexts, authentic tasks, active, autonomous learning and cooperative learning, and an adaptive curriculum. In addition, Kebritchi and Hirumi (2008), reviewing game-based learning publications and educational games, suggested that "[d]irect instructional teacher-centered methods ... are giving way to more learner-centered approaches" (p. 1739). These arguments are reminiscent of those by Jonassen and Reeves (1996) who argued that technology should not be used as instruction to learn from, but rather as a cognitive tool for construction of new knowledge, that is a learning with approach. More recently, Amiel and Reeves (2008) suggested that for technology to positively influence learning outcomes, technology should rather support complex human, social and cultural interaction and not function as the artifact for learning.

It could be therefore be argued that for games to successfully support learning and teaching they should be designed as complex games and function as tools to mediate learning outcomes. However, I argue that the predominant uses of games in the classroom are trivial games that support a learning from position.

\section{Learning from games}

In a recent analysis of computer games as learning tools Ke (2008a) summarised previous meta-analyses and reviews, and qualitatively investigated 89 publications. Ke (2008a) identified a number of themes from previous reviews that included the following:

1. While there are articles on the proposed potential of games to support teaching and learning, there are fewer reports that addressed the effectiveness of games in the classroom;

2. Little empirical evidence exists to illustrate that playing games leads to learning in all situations;

3. Evaluations of educational use of games has been anecdotal, descriptive, or judgmental;

4. Longitudinal studies have not been undertaken; and

5. Some domains such as mathematics, physics, and language arts appeared to be better suited to gaming.

A large proportion of the articles (73\%) analysed by Ke (2008a) compared conventional instructional methods with standalone pedagogical instruments or drill and practice (trivial) 'games'. Additionally, game design studies (19\% of the sample) highlighted the need for instructional support to be embedded within the instructional game (a learning from approach). Ke (2008a) also found that more knowledge on how games 
can be orchestrated with pedagogical practices is required, information on instructional games and learner characteristics is limited, and that cognitive outcomes as a result of game play included basic motor skills, descriptive knowledge, conceptual knowledge, problem solving and generative cognitive strategies. Ke (2008a) used the term instructional games and argued that "best practices of designing and applying instructional gaming would form by carefully aligning and integrating the three clusters of key variables - learning, learner, and instructional game design". Such a position favours a 'games as tutors' approach: the technological artifact acts as a tutor (learning from).

Ten years after Amory et al. (1999) reported that students found games educationally motivating, Papastergiou (2009) still reported that educational computer games can impact student motivation but showed that students who played a trivial game of solving a maze puzzle performed no better than those who made use of a non-gaming educational web site. Similarly, Ke $(2008 b)$ reported that students showed positive attitudes to learning mathematics without any effect on their cognitive abilities when they played trivial, computer mathematical drill games. Gunter, Kenny and Vick (2008) suggested that "[i]f a game is intended to teach academic content on a standalone basis" then the "targeted content needs to be intrinsically coupled with the fantasy context" ( $p$ 517). Such an approach again supports learning from technology. These results suggest that when an educational game acts as the communicator of instruction (tutor) there appears to be little change in student performance. But, this position is challenged by researchers who view learning from a constructivist position.

\section{Learning with games}

Using an approach based on narrative theory and students as co-designers, Waraich and Brna (2008) showed that game play by the students led to improved performance. In addition, successful learning occurred when 10 year olds designed and created their own games (Robertson \& Howells, 2008). These participants were enthusiastic, determined to complete the tasks, worked both individually and collectively, and could apply what they learnt to other situations. Such reports suggest that during collective game design, a learning with approach, technology acts as a cognitive tool and this leads to meaningful learning. Just as collaborative design supports learning, so too is social collaborative participation during game play important.

Squire, DeVanve and Durga (2008) showed that disenfranchised students developed academic skills and productive identities as consumers and producers of information when they played a historical simulation game supported by a community of game experts. In addition, Kiili (2008) argued that teachers, as non-player game characters, provided scaffolding to support learners in game-based learning situations. Verenikina, Herrington, Peterson and Mantei (2008) showed that group play supported imaginative make believe as an important learning strategy used by young children. Foko and Amory (2008) reported that students from disadvantaged backgrounds showed no improvement in understanding photosynthesis and respiration when they played an educational game on their own. However, playing in pairs and using the game puzzles to stimulate social dialogue, students overcame most of their misconceptions. Seagram and Amory (2005), using qualitative and quantitative methodologies, investigated learning through playing a game created to address serious South African diseases (tuberculosis, AIDS/HIV, cancer and virus infections). In this instance, groups of players who discussed the puzzles develop a deep 
understanding of the embedded concepts - the longer the participants discussed certain knowledge domains, the richer were their descriptions.

Kim, Park and Baek (2009) showed that meta-cognitive strategies, such as recording, modeling and thinking aloud, influenced social problem solving abilities and academic performance in a 'Massively Multiple Online Role Playing Game'. Kim et al (2009) argued that the meta-cognitive strategies mediated between game play and cognition and that thinking aloud supported self-regulated learning. They suggested that during mediation social interactions (inter-psychological processes) were transformed into internal cognition (intra-psychological processes) -- a Vygotskian position. Squire $(2008,192)$ wrote "[w]e are still in the early stages of creating theories of game-based learning environments, but I believe that open-ended, sandbox-type environments (exemplified here by GTA: SA and Civilization) are excellent places to start" (my emphasis). However, playing of the game Civilization only fostered identity development and learning when more knowledgeable game players acted as mentors (Squire, 2008; Squire et al, 2008). All of these indicate that Vygotsky's Zone of Proximal Development (ZPD) is the cognitive and social space resulting in learning:

\begin{abstract}
When it was first shown that the capability of children with equal levels of mental development to learn under a teacher's guidance varied to a high degree, it became apparent that those children were mentally not at the same age and that subsequent course of their learning would obviously be different. This difference between twelve and eight, or between nine and eight, is what we call the zone of proximal development. It is the distance between the actual developmental level as determined by independent problem solving and the level of potential development as determined through problem solving under adult guidance, or in collaboration with more capable peers (Vygotsky, 1933/1978, p. 86).
\end{abstract}

In these examples, game play supported learning when the students were part of the design team (Waraich \& Brna, 2008), designed their own games (Robertson \& Howells, 2008), when mentored by experts (Squire et al, 2008), and were involved in social collaborative game play and puzzle solving (Seagram \& Amory, 2005; Foko \& Amory, 2008; Verenikina et al, 2008; Kim et al, 2009). Thus, an alignment of educational computer video games with constructivist learning theories, as articulated variously by, among others Vygotsky (1933/1978) and Piaget (1977), offers the most likely theoretical positions to support the use of games in the classroom. More specifically, the contemporary theoretical descendant of Vygotsky's work, namely Cultural Historical Activity Theory (CHAT) can be used both as an analytical frame to design educational games and as a means to understand tool-mediated knowledge construction through game play.

\title{
Cultural Historical Activity Theory
}

CHAT originated from the earlier work of Vygotsky (1933/1978) and Leont'ev (1978). More recently, Engeström (1987), in order to better understand human activity and work, expanded the original Vygotskian subject-object-tool triad to include rules, the community and division of labour (Figure 1). In education, this model has become a valuable 'gazing' or heuristic tool for the design and evaluation of learning tools and environments. For example, CHAT was used to design constructivist learning environments (Jonassen \& Rohrer-Murphy, 1999; Jenlink, 2001), work (Engeström, 2000), learning with ICTs (Issroff \& Scanlon, 2002), educational software (Puustinen, Baker \& Lund, 2006) and mobile learning (Uden, 2007). With respect to evaluation, CHAT was used to study the use of ICTs in schools (Lim, 2002), software development 
environments (Barthelmess \& Anderson, 2002), online communities (Barab, Schatz \& Scheckler, 2004), technological knowledge development (Stevenson, 2004), learning technologies (Scanlon \& Issroff, 2005), teacher perception of the use of ICTs in schools (Hardman 2005), cognitive tools (Shaffer \& Clinton, 2006), human-computer interaction and games (Barr, Noble \& Biddle, 2007), e-learning (Benson, Lawler \& Whitworth, 2008) and effect of technology on teaching practice (Blin \& Munro 2008).

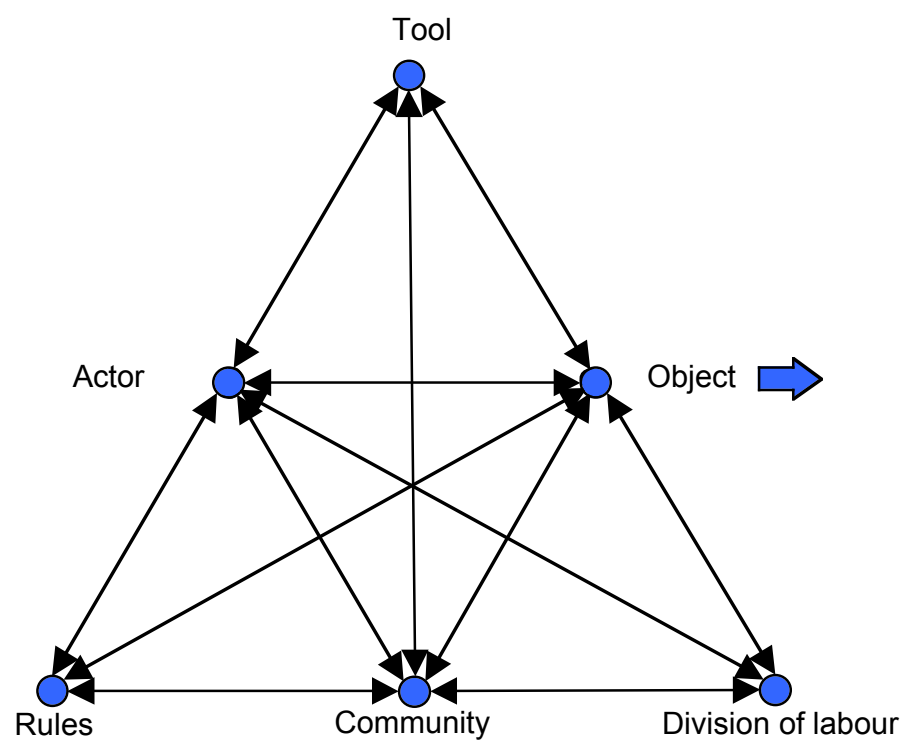

Figure 1: Activity system diagram (redrawn from Engeström, 1987).

Leont'ev (1978) stated that all human activity takes places within a social and cultural context and is a process in which one or more actors transform an object. Objects, as cultural entities, embody communal social practices that transform and further develop during human activity (Stetsenko, 2005). Therefore, the Outcomes of any activity result from Actors interrogating Objects by means of Tools that mediate the interactions. In addition, the Rules mediate relationships between Actors and the Community and the Division of Labour mediates between the Community and the Object (Engeström, 1987, 2000, 2001; Barab, Evans \& Baek, 2004; Roth \& Lee, 2007). Internal Contradictions are not seen as problems but as source of development and therefore play important roles in any activity system as they drive the development of and changes in the system (Engeström, 2000, 2001). The prime unit of analysis is the Object that also gives the system its coherence (Engeström, 2001). In addition, socially created Tools are inseparable from the associated activity (Robbins, 2005). However, confusion often surrounds the use of the word "object" in the English language. Kaptelinin (2005) explained that the Russian objekt and predmet both translate to 'object' and mean "material things existing independently of the mind" and "target or content of a thought or an action" respectively ( $p$ 8). Nardi (2005) posited that the first meaning is related to that "which is to be realized" ( $p$ 39) and the second could be seen as the "object of desire" ( $\mathrm{p}$ 40). As such, the Object and Motive should be separated (Kaptelinin, 2005) and when we instantiate an object we formulate it, and realise an object when we reach as outcome (Nardi, 2005). Examples by Jenlink (2001) (Figure 2) 
and Blin and Munro (2008) (Figure 3) illustrate the use of CHAT in the design of an educational system and evaluation of learning activity respectively.

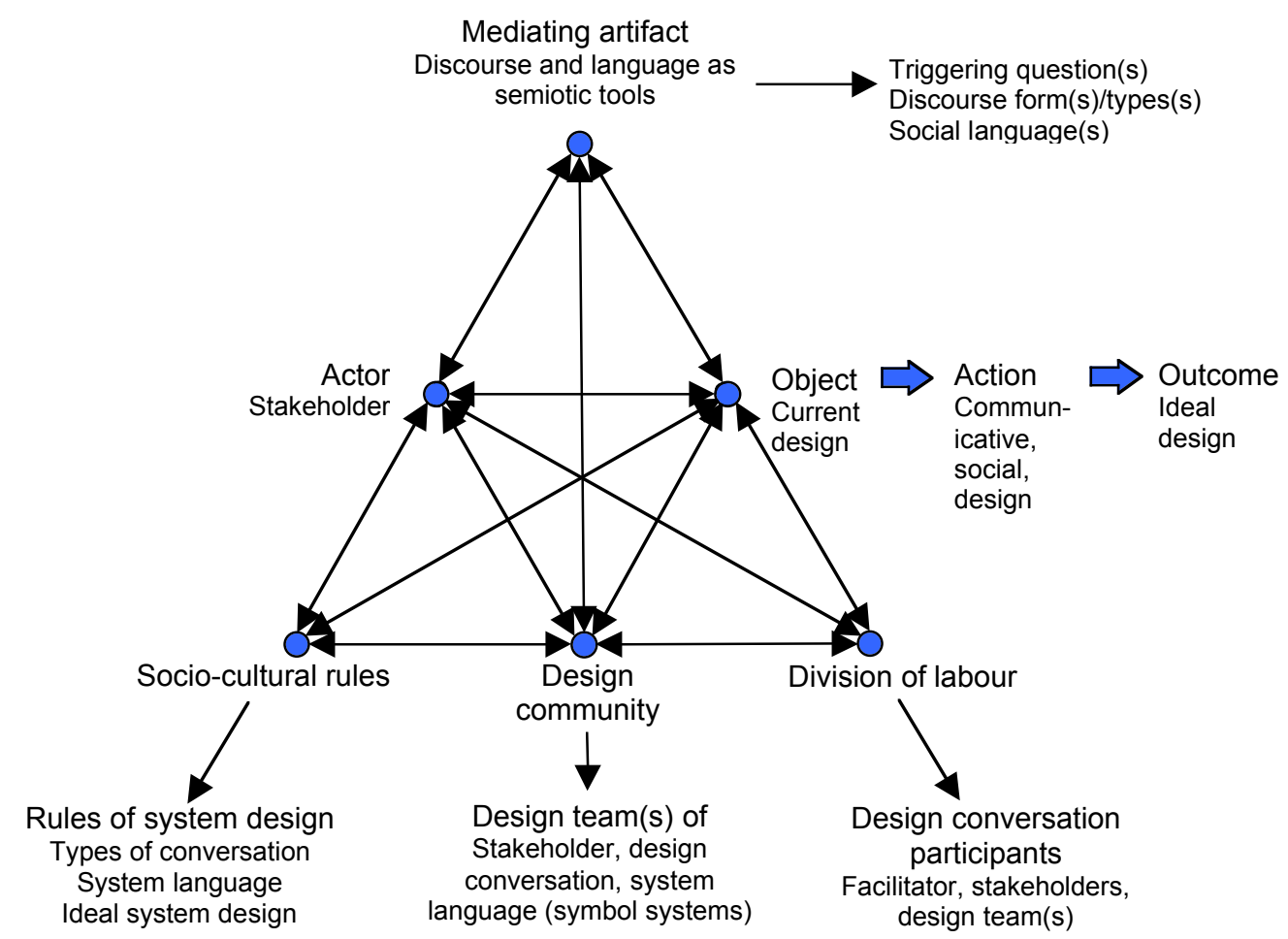

Figure 2: Activity system diagram describing the design of an educational system (redrawn from Jenlink, 2001).

With respect to the use of games in the classroom, it was argued that games are mostly used as tutors, a learning from position rather than as tools to mediate learning, a learning with position. When a game functions as a tutor it becomes the Object of the activity, while games that mediate learning outcomes function as Tools associated with the learning activity.

This paper uses CHAT as a heuristic to frame the social and cultural interactions during the use of an educational computer video game, mediating the learning task to construct biological knowledge related to cancer, malaria, tuberculosis and HIV / AIDS. In this investigation the game acted as a Tool to mediate the Object of the activity and not as the Object. The educational computer video game, yKhozi-The Burning Ground (Seagram, 2005), instantiates a number of puzzles related to the Object of the activity. Participants, 14 to 19 years old students from Soweto, South Africa, attempted through collaborative problem-solving and game play to realise the desired Outcomes (engaging with the biology of a number of diseases) and to reconstruct the game narrative. In this approach, the game puzzles act as disruptions designed to drive the learning activities. The CHAT framework is not used to investigate participant cognitive development in this study, but rather to analyse Tool, Object, and Outcome to gaze at collaborative game play. 


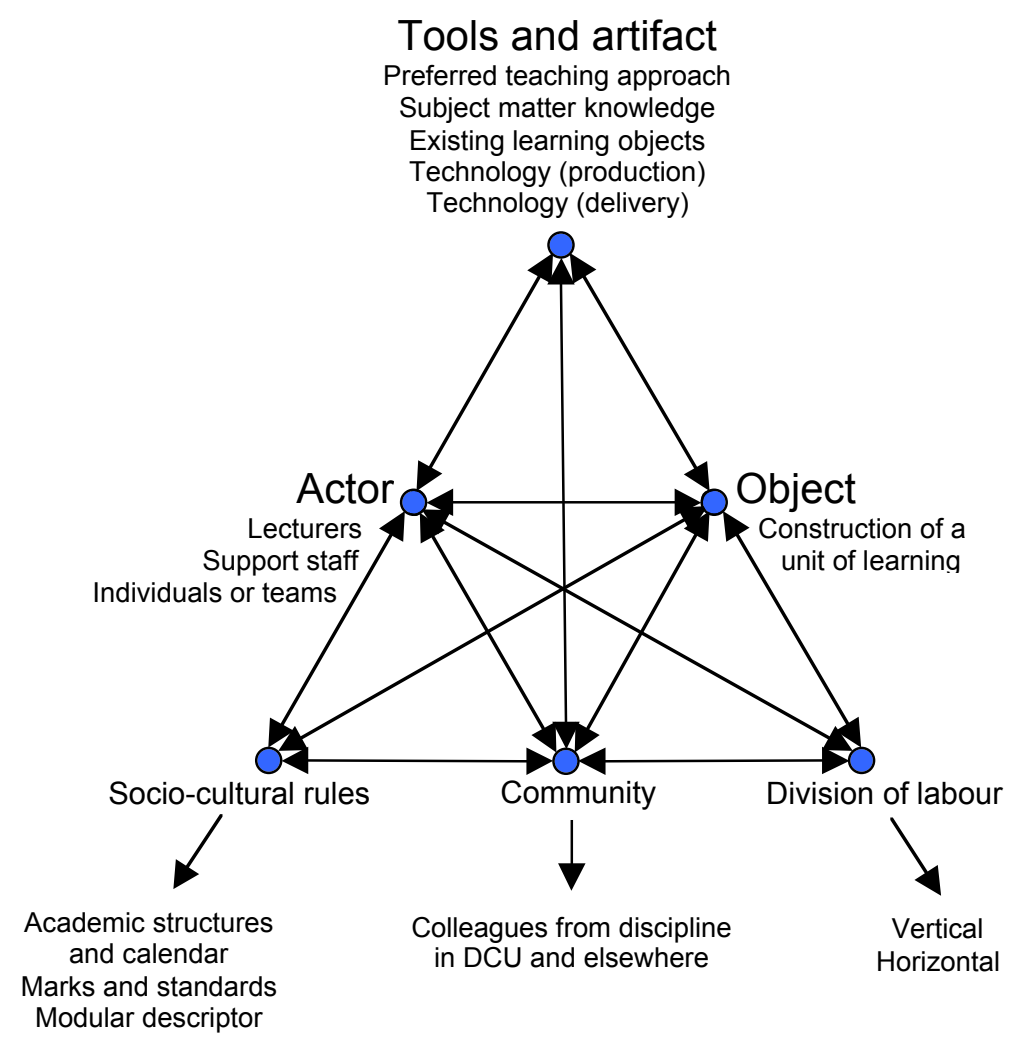

Figure 3: Activity system diagram describing the evaluation of a learning activity (redrawn from Blin and Munro, 2008).

\section{Materials and methods}

\section{Research design}

In this case study (Creswell, 1998; Merriam, 2002; Heck, 2006) an educational game is used in a collaborative learning process, as suggested by Amiel and Reeves (2008), and not as the artifact, or tutor, for instruction. First, the unit of analysis is thus not the technological artifact itself (the game in this case), but rather the process of students engaging with the technological tool to develop insights into the biology of cancer, malaria, tuberculosis and HIV/AIDS. Second, research needs to inquire "into techniques and tools in an effort to improve and refine the process of teaching and learning and, consequently, the design of learning environments" (Amiel \& Reeves, 2008,32 ). Third, the study was bounded by time (participants played the game over 4 days), place (a computer lab at the University of Johannesburg) and the participants. Lastly, research instruments included a knowledge test (analysed quantitatively) and reflective journals, round-robin discussion and observations (analysed qualitatively) that are used to develop a rich description of the "learning with" games phenomenon, or tool-mediated knowledge construction. 


\section{Problems statement}

While many researchers agree that computer video games could play an important role in teaching and learning, most of the current research has:

1. Concentrated on what participants feel;

2. Compared the use of games versus some other form of instruction; and

3. Made use of games as tutors in the classroom - a learning from approach.

Therefore, games are mostly viewed as instructional media and the associated teaching practices use technology as a means of instruction rather than tools to support knowledge construction. To address this problem, I argue that games should rather be used as a tool to mediate a learning outcome in a social constructivist learning context. Hence, the research reported here makes use of an educational game to mediate the learning about the biology of cancer, malaria, tuberculosis and HIV/ AIDS.

\section{The context}

Twelve 14 to 19 year old black orphans from a non governmental organisation (NGO) situated in Soweto, South Africa, participated in a program at the University of Johannesburg to develop their ICT skills. Many of the participants were orphaned due to the AID/HIV pandemic. Participants were transported to the University from and to Soweto each day and were accompanied by a caregiver from the NGO. Informed consent to participate in this study was obtained from participants as well as their guardians.

Participants, a caregiver and four researchers interacted in the Faculty of Education's computer laboratory. The interactions were designed to allow the participants to collaboratively solve specific problems through the use of ICTs. Afternoon activities during the first three days of the program included the collaborative playing of the game $y$ Khozi-The Burning Ground as the fun part of the day's activities. Groups included both sexes and included three participants per group. During game play facilitators did not show the participants how to solve the puzzles but provided scaffolding for them is solve the puzzles themselves. All participants shared morning tea and a midday meal.

An educational game called yKhozi-The Burning Ground designed for adolescents by Seagram (2005) using the Game Object Model (GOM) (Amory, Naicker, Vincent, \& Adams, 1999; Amory \& Seagram, 2003) was used in the study. A brief description of the design of the game is provided as background into this socially constructed learning tool. The GOM marries pedagogical practices with game design principles, and puzzle solving is the core component of the game design. yKhozi-The Burning Ground was designed to specifically develop knowledge into the:

1. Transmission and biology of HIV / AIDS, malaria and tuberculosis;

2. Biology and mechanism of cancer; and

3. Differences between viruses and bacteria and the role of protists in malaria (Seagram, 2005).

In this game the puzzles directly address these learning outcomes and are linked into a hierarchy (Figure 4 ) that drives the game narrative, fosters reflection during game play 
and leads to game resolution. The game provided a realistically rendered play space, an African village, and the development of solutions to the authentic tasks (puzzles) required active collaboration, as suggested by Smeets (2005). During game play facilitators encouraged participants to discuss possible game puzzle solutions and helped them, when required, to find relevant information distributed within the game space.

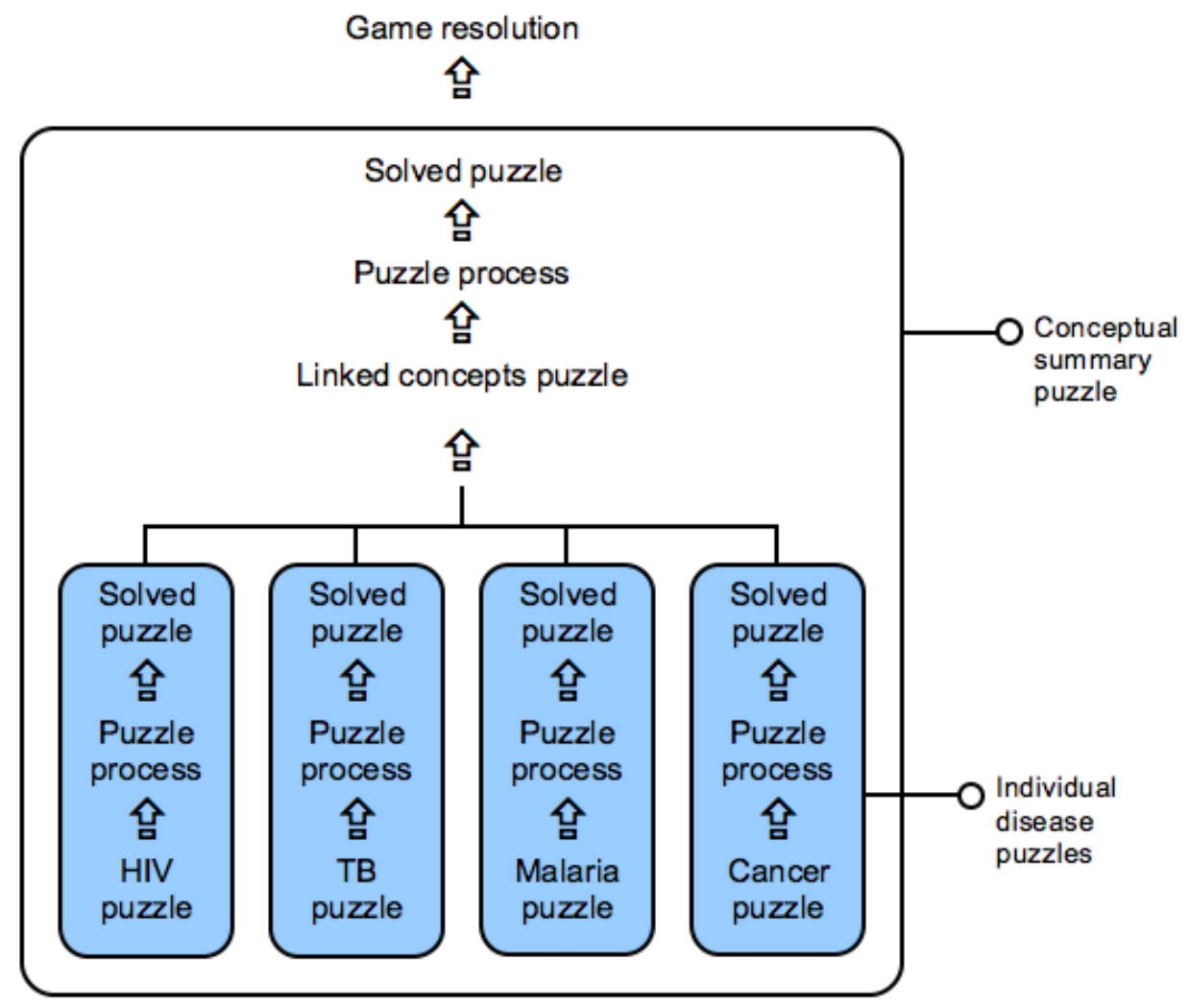

Figure 4: Hierarchical structure of the puzzles (redrawn from Seagram, 2005).

\section{Research instruments}

Researchers, as discussed below, made use of a questionnaire to evaluate knowledge construction, reflective journals and a round-robin discussion to consider participants opinions, and research observations.

Questionnaire to evaluate knowledge acquisition

Analyses by Lana (1969/2009) suggested that pre-tests associated with learning, such as recall of previously learnt material, had a direct and positive effect on the magnitude of post-test scores or in some conditions depressed the post-test scores. Lana argued that the influence of a pre-testing could be minimised by increasing the time between pre- and post-testing. Such findings were supported by Dochy, Segers and Buehl (1999) who posited that there is a strong relationship between prior knowledge and performance, and that prior assessment strongly influenced learning 
outcomes. The use of a sensitising pre-test just prior to exposure to a multimedia, interactive system increased learning (Bos, Terlouw \& Pilot, 2007). Therefore to remove the sensitisation caused by pre-testing and due to short research time frame (four days), participants in this inquiry were tested after game play and their performance compared to the participants used in the Seagram's (2005) study.

A questionnaire, based on the work of Seagram (2005), was administrated to participants on day four of the interaction to measure their knowledge related to the transmission and biology of cancer, malaria, tuberculosis and HIV/AIDS. This instrument was designed to identify the poorly understood knowledge areas related to the biology of the diseases. Based on a literature review Seagram (2005) developed an instrument that consisted of multiple choice questions. Pilot testing of the instruments was with 35 first year science and engineering students at the University of Natal. Participants completed the questionnaire in their own time and thereafter ten of them, which included five who were not first language English speakers, discussed together questions that were unclear. These interactions allowed the identification of questions that were difficult, confusing, too complex, or used confusing terminology. The final questionnaire therefore used simpler language, less confusing terminology and more concise sentence structure. The questionnaire was administered to first year biology $(n=100)$ and engineering students $(n=156)$ at the University of Natal.

The results of this questionnaire were used to identity and design the game puzzles. For this case study three questions, considered to contain complex biological terminology, were deleted. Participants in this study $(n=12)$ answered the questionnaire on day four of the program after playing the games for at least six hours. As the English reading and writing skills of participants were poor, each question was read aloud to the participants during the evaluation period. In order to minimise bias the multiple choice answers were not read to the participants. Participants' individual scores were determined and the mean and standard deviation calculated. Questionnaire items are directly related to specific concepts (Table 1). The percentages of correct answers per concept were calculated.

The research reported here makes use of minimal statistical analyses due to the small sample size. However, descriptive comparisons between the different samples (participants in this and those from the Seagram study), using MedCalc version 11.2 (http://www.medcalc.be/), are reported. The data sets from the Seagram and this study were normally distributed ( $p>0.2$ using Kolmogorov-Smirnova and ShapiroWilk tests respectively). These comparisons are made to determine equivalent, and not statistically different, performances.

\section{Reflective journals}

At the end of each day participants reflected, in writing, on what they had learnt and the researcher reflected on classroom activities and interactions. These journals were deductively coded and categorised against the CHAT framework (Henning, van Rensberg \& Smit, 2004).

\section{Round-robin discussion}

At the end of the first week participants participated in a round-robin discussion and reflected, in English or their mother tongue, on their experiences and what they thought they had learnt. One of the facilitators provided translations into English when required. 
Table 1: Different knowledge concepts used to evaluate knowledge related to viruses and bacteria, HIV/ AIDS, cancer, malaria and tuberculosis

\begin{tabular}{|c|l|}
\hline Index & \\
\hline 1 & Viruses reliance on host and ability to cause disease \\
\hline 2 & Bacterial independence, pathogenic ability and ubiquitous distribution \\
\hline 3 & HIV linked to AIDS \\
\hline 4 & Transfer of HIV \\
\hline 5 & Prevalent form of HIV transmission in Africa \\
\hline 6 & $\begin{array}{l}\text { Condom usage, safe sex and the role of other sexually transmitted diseases in risk of } \\
\text { contracting HIV }\end{array}$ \\
\hline 7 & Reliability and mechanism of the HIV/AIDS test \\
\hline 8 & Asymptomatic nature of HIV infected persons \\
\hline 9 & $\begin{array}{l}\text { Mechanisms of cancerous spread, including tumour progression, role of genetic } \\
\text { mutations in cancer and abnormal apoptosis }\end{array}$ \\
\hline 10 & Causes of cancer \\
\hline 11 & Possible transmission routes of cancer, including inheritability \\
\hline 12 & Causative agent of malaria \\
\hline 13 & Virulence of different malaria strains \\
\hline 14 & Prevention of malarial transmission \\
\hline 15 & Causative organism of tuberculosis \\
\hline 16 & Transmission of tuberculosis \\
\hline 17 & Groups most at risk of contracting tuberculosis \\
\hline 18 & Role of environment in tuberculosis spread \\
\hline
\end{tabular}

\section{Results}

\section{Questionnaire to evaluate knowledge}

Participant performance is compared to the results of the same knowledge test used in the Seagram (2005) study used to identify misunderstood concepts in biology and nonbiology participants. Therefore, the efficacy of game play should foster knowledge construction, and thus participants in this study should perform better that those who were used to identify the poorly understood knowledge areas.

Participants in this study $(n=12)$ scored above $50 \%$ for 12 out of the 18 concept categories (Table 1) included in the assessment instrument. Their performance (Figure 5 ) is discussed in relation to the results obtained by Seagram (2005) from first year biology and non-biology students.

The teenagers in this study better understood a number of concepts when compared to the first year biology university students. These better understood concepts related to the prevalent form of HIV transmission in Africa (concept 5), condom usage, safe sex and the role of other sexually transmitted diseases in risk of contracting HIV (concept 6), reliability and mechanism of the HIV/AIDS test (concept 7), causes of cancer (concept 10), virulence of different malaria strains (concept 13), prevention of malarial transmission (concept 14) and groups most at risk of contacting tuberculosis (concept $17)$.

The participants in this study also performed better than did the non-biology first year tertiary students (from the Seagram study) in concepts related to bacterial independence, pathogenic ability and ubiquitous distribution (concept 2), possible transmission routes of cancer, including inheritability (concept 11) and the role of the environment in tuberculosis spread (concept 18). 


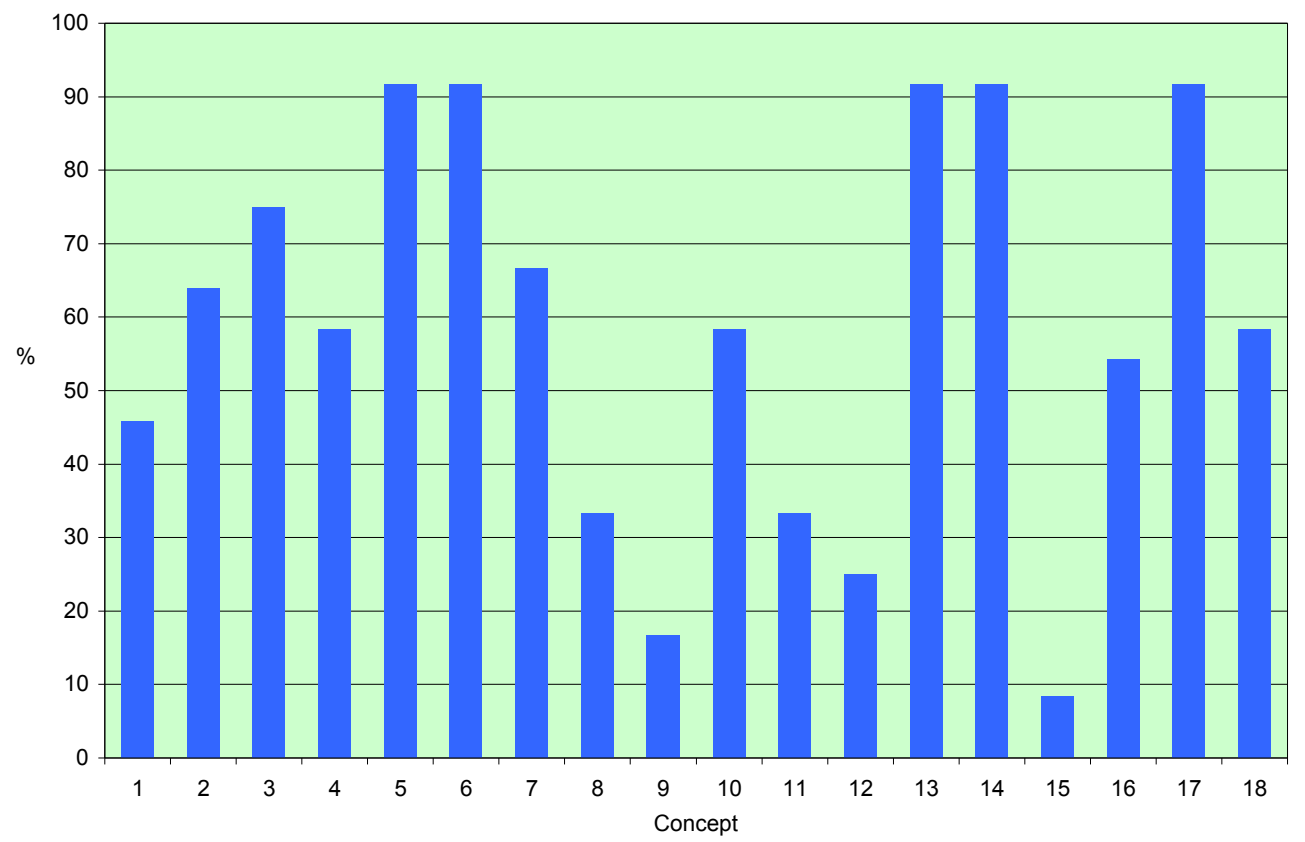

Figure 5: Average scores by participants for each concept category of the questionnaire.

However, members of this study group performed worse than either the biology or non-biology students in concepts related to viruses reliance on host and ability to cause disease (concept 1), asymptomatic nature of HIV infected person, mechanisms of cancerous spread (concept 9), causative agent of malaria (concept 12), causative organisms of tuberculosis (concept 15) and transmission of tuberculosis (concept 16).

Teenage participants $(n=12)$ in this study scored an average of $57.1 \pm 8.9 \%$ for the multiple choice instrument designed to measure their understanding of the biological concepts included in the computer video game. This score is statistically similar to that obtained by first year biology students $(61.4 \pm 10.2 \%)(\mathrm{t}$-test $=1.4, \mathrm{DF}=110, \mathrm{p}=0.165)$ and significantly better from the score obtained by first year non-biology students ( $37.6 \pm$ $8.1 \%$ ) (t-test=-7.982, DF=116, $\mathrm{p}<0.001)$.

\section{Journal content analyses}

Deductive content analyses involved the use of the CHAT frame as a lens to investigate participants' writings. The two most important themes that emerged from the content analyses of the participants' reflective journals were that they recognised that the game (Tool) mediated their learning, and they were able to identify the Object of the activity, learning about the biology of the diseases. In addition, a few of the participants identified the Outcome of the activity and some discussed how they might help their Community. Each of these CHAT elements will now be discussed in some detail. 


\section{Tool-mediated learning}

Comments varied from the general to the more complex. For example, one individual mentioned that they "learned how to play a game" before saying they learnt to "open a computer" (i.e. switching on the device). "A game that gave me an information that I didn't have and that is a plus for me" and "[t]oday I've learned lots of things about cancer and HIV/AIDS which I thought were very good points to protect us. I really hope we learn more about different disease" indicated that the game presented participants with valuable information. The comments

I have enjoyed the game that I was playing it was so brilliant to do that game because it made us to rellise that from this dieses effect your body. Especially in AIDS \& T.B that was the most shamefull things that I saw during the game, it teaches me everything that happens to you when you got this different dieses

showed that through game play this participant could relate the information to their own life. It was interesting to observe that the game puzzles stimulated discussion and encouraged curiosity. When participants were unable to solve a particular problem, facilitators showed them how to find the information. The players quickly learned to refer to the embedded texts in the game to help them solve problems. Nearly all of the participants referred to how the game taught them new knowledge but only some of them realized that solving the puzzles facilitated learning. For example

\footnotetext{
[a]t least we were able to tell other learners what did we learn during the process in the task" (my emphasis)

and

... the game was easy at the beginning but when you get going through it became

more difficult ... cannot make to struggle. So after I told that to my self I began to have more strength and I scored 3 names from the pazzle wich was difficult to my members to find a word in it".
}

Object of the activity

yKhozi-The Burning Ground was designed to foster an understanding of the biology of tuberculosis, HIV/AIDS, cancer and virus infections which is realised through game interactions, game character personal stories, and puzzles. Within 10-15 minutes of play many participants had already recognised the setting, an African village, and identified that the narrative included death most probably linked to HIV/AIDS. Reflections made by participants when they discuss the diseases and, in particular, the puzzles, indicated that they were able to identify the Object of the learning task. For example

I was learning about cancer and Hiv \& Aids

and

I like the game because it teaches about aids, cancer and malaria that those things

killers and that shows us that our life are important and that you must take care of you life and respect it.

One of the participants made a more direct reference to the biology of the diseases: "Today I learnt about how Hiv looks likes and how tubercoulosis look and Cancer and Malaria". Reflecting on the knowledge questionnaire another participant wrote:

... will give us questionier on the information that we learned from the game. So tell me if I did took that game for granted or have been lazy to read it what would have happened to me so far, I wouldn't have answered the questions about cancer, tubercouloses etc. 
Such reflection indicated that they understood that playing the game was learning about the diseases.

Outcome of playing the game

Completing the task was important as "I hope that next time tomorrow I'll finish the game and be more clever when it comes to teckniks of games". During the second day of play one group noticed that another group had collected more in-game items and suggested that their group needed to work harder. Such inter-group competition also stimulated group discussion.

Good group interaction and support resulted in faster progress in the game: "I am proud of my group, we did well on the 'yKhozi' game, we shared ideas and managed to finish". This group was the first to complete the game and was very pleased with their achievements. Another group decided on day two that they would no longer play together, and rather solve the puzzles individually. On day three they were encouraged to play together. This group was the only one that did not to complete the game.

\section{Community}

The comments "I wish I could advice others about these affections and not to have sex without condoms" and "I wish I could advice them about T.B." illustrated that playing of the game provided this participant with knowledge that they considered important for a larger community.

\section{Round-robin discussion}

During the open discussion three male participants commented on playing the game. The first participant found the game educational, learnt interesting information and felt that he would be able to solve problems related to HIV/AIDS in the future. The next participant's comment related to his confidence. The young man said that he had learnt about cancer and AIDS and felt that he could now share his knowledge with others. The third participant argued that as the game provided correct information he was able to make better judgments in the future. These comments indicated that participants thought that by playing yKhozi-The Burning Ground they became more informed and that their knowledge would help them and their community in the future. By understanding the Object of the activity, the biology of the diseases, and being part of a Community they demonstrated Tool-mediated learning.

\section{Discussion}

The aim of this case study was to explore the use of a complex computer video game to teach young people about the biology of a number of diseases including HIV / AIDS and to discover the game narrative. I argued that computer video games should be used as a tool to mediate learning outcomes in a social constructivist learning context (Figure 4). Furthermore, the design of the learning task was not to use the game as an instructional tutor, but as a tool to mediate questioning, discussion and collaborative problem solving (Figure 6). The unit of analysis in this case study is therefore associated with the Object and Outcomes of the activity: knowledge of the biology of a cancer, tuberculosis, malaria and HIV/AIDS and the reconstruction of the game narrative (Figure 6). The Actors involved in the collaborative problem solving gaming environment included the student participants and the facilitators who guided the students but did not provide solutions to the problems (Figure 6). 
With respect to knowledge construction, the secondary school participants in this study did not score statistically differently than did first year biology students. In some instances, they outperformed first year university biology students in a number of concepts. Most notable were concepts related to the prevalence of HIV/AIDS transmission and the use of condoms. Such performance differences may be the result of the HIV/AIDS campaigns delivered to young South Africans over the past few years in schools nationwide. However, the participants were more familiar with the reliability and mechanisms of the HIV/AIDS test than the first year biology students and this knowledge is not part of HIV/AIDS campaigns. The school participants understood many concepts that non-biology learners did not.

However, they did not understand a number of concepts related to the causative agents and transmission vectors of the diseases. For example, most of the participants identified the causative agent for malaria as mosquitoes, and not the plasmodium parasite. It is not difficult to understand why participants had a great deal of difficulty with these concepts as this is a widely held misconception. These results suggest that the participants in this study learnt new knowledge related to the biology of tuberculosis, HIV / AIDS, cancer and virus infections. Therefore, the school participants developed knowledge and insights into the biology of cancer, HIV / AIDS, tuberculosis and malaria, and were able to relate the game story (Figure 6). This finding is supported by the participant's own voices.

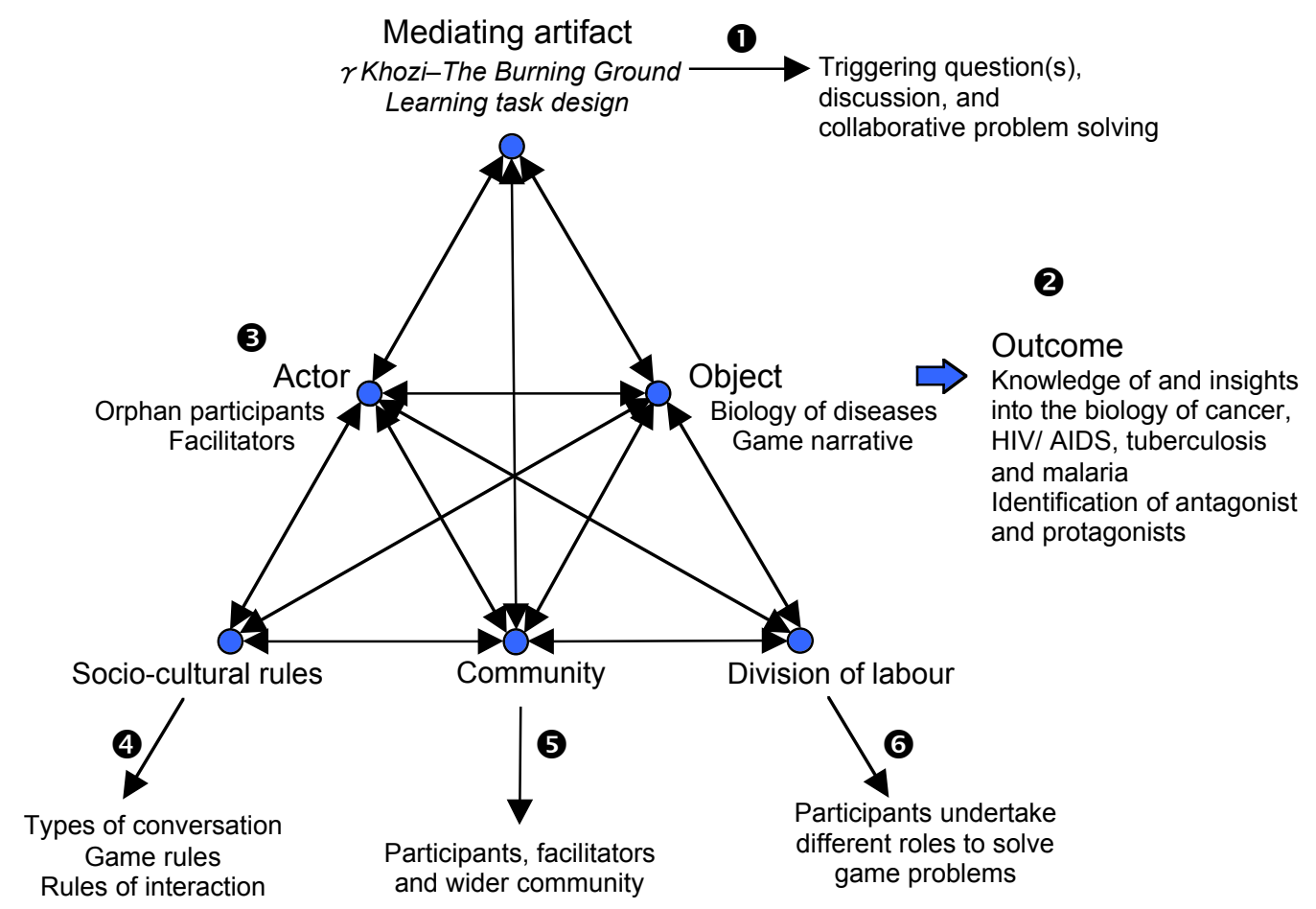

Figure 6: An activity system illustrating game-mediated knowledge construction. 
They clearly articulated that by playing the game they came to understand the biology of the diseases, especially HIV/AIDS and tuberculosis. Such understandings, they thought, were a result of trying to solve the puzzles collaboratively and indicated that learning was a process of engagement in the game tasks and therefore understood the rules of collaboration, game play and interaction (Figure 6). In addition, through playing the game they clearly understood that the Object of the activity was to develop an understanding of the biology of the diseases (Figure 6). They were proud of their achievements and mentioned how their different roles related to collaboration and competition (Figure 6) that helped them to complete the game. Not only did they enjoy playing the game, but they felt that their experience empowered them to support their community (Figure 6).

These findings advocate that learning activities that are object-orientated and toolmediation led to new knowledge construction that might benefit both individuals and their communities. The learning task design, in this case, was supported by an authentic, richly textured and complex game environment in which learners and facilitators worked together to solve problems. The puzzles embedded in the game brought to the foreground contradictions that were resolved through collaborative actions.

This case study illustrated that the learning task is more important than the artifact, the computer video game. That is, technology should facilitate the learning process. Therefore, in the learning task the educational game was neither the unit of analysis nor the Object of the activity. The game puzzles functioned as a Tool to facilitate knowledge construction supporting the ideas of Jonassen and Reeves (1996) and Amiel and Reeves (2008). In addition, this Tool was designed to foster learning by presenting students with an authentic setting that included complex puzzle-solving. However, without the support of peers, individuals who worked alone took longer to complete the tasks (personal observation). The participants therefore realised that social collaboration is an import part of learning. Kim et al (2009) argued that thinking aloud and modeling as part of game-based learning could mediate between game play and cognition. Similarly, in this case the design of the game puzzles, when solved collaboratively, could mediate between game play, knowledge construction and cognition.

While Squire (2008) argued that there is a need to create new theories for game-based learning environments, the findings of this case study support the argument that "human activity - material, practical, and always, by necessity, social collaborative processes aimed at transforming the world and human being themselves with the help of collectively created tools - is the basic form of life of people" (Stetsenko, 2005, 72). In addition, results presented here support Jonassen and Reeves' (1996) contention that technology should be used as a cognitive tool in constructivist learning environments. The case presented here posits that for computer video games to be part of classroom practices, the games must be part of a socially collaborative learning experience and should act as tools, and not as tutors, to mediate learning objectives. However, as this is a case study with a small sample size, the findings cannot be generalised. Further research should be conducted to test the transferability of the findings to other contexts that include a larger number of participants who play complex games for extended periods of time. 


\section{Acknowledgments}

I would to thank the University of Johannesburg Research Committee who provided funding for this project. Thank you to Geoff Lautenbach, Gert van der Westhuizen, Elizabeth Henning and Katalin Morgan for their critical reading of the manuscript. Lastly I thank my colleagues Barbara Fisher, Jerry Maseko and Rabaitse Diseko for their contributions to the project.

\section{References}

Amiel, T. \& Reeves, T. C. (2008). Design-based research and educational technology: Rethinking technology and the research agenda. Educational Technology E Society, 11(4), 29-40. http: / / ifets.info/journals/11_4/3.pdf

Amory, A. (2007). Game object model version II: A theoretical framework for educational game development. Educational Technology Research \& Development, 55(1), 51-77. [verified 16 Oct 2010] http:/ / www.fi.uu.nl/publicaties/literatuur/endnote_ecgbl_930_amory.pdf

Amory, A. \& Seagram, R. (2003). Educational game models: Conceptualization and evaluation. South African Journal of Higher Education, 17(2), 206-217.

Amory, A., Naicker, K., Vincent, J. \& Adams, C. (1999). The use of computer games as an educational tool: 1. Identification of appropriate game types and game elements. British Journal of Educational Technology, 30, 311-322.

Barab, S. A., Evans, M. A. \& Baek, E. O. (2004). Activity theory as a lens for characterizing the participatory unit. In D.H. Jonassen (Ed.), Handbook of research on educational communications and technology (pp. 199-214). Washington, DC: Association for Educational Communication and Technology.

Barab, S., Schatz, S. \& Scheckler, R. (2004). Using activity theory to conceptualize online community and using online community to conceptualize activity theory. Mind, Culture and Activity, 11(1), 25-47.

Barr, P., Noble, J. \& Biddle, R. (2007). Video game values: Human-computer interaction and games. Interacting with Computers, 19(2), 180-195.

Barthelmess, P. \& Anderson, K. M. (2002). A view of software development environments based on activity theory. Computer Supported Cooperative Work, 11(1), 13-37.

Benson, A., Lawler, C. \& Whitworth, A. (2008). Rules, roles and tools: Activity theory and the comparative study of e-learning. British Journal of Educational Technology, 39(3), 456-467.

Betz, J. (1995). Computer games: Increases learning in an interactive multidisciplinary environment. Journal of Educational Technology Systems, 24, 195-205.

Billen, A. (1993). Could it be the end for Super Mario? The Observer, 27 June.

Blin, F. \& Munro, M. (2008). Why hasn't technology disrupted academics' teaching practices? Understanding resistance to change through the lens of activity theory. Computers $\mathcal{E}$ Education, 50(2), 475-490.

Bos, A. B. H., Terlouw, C. \& Pilot, A. (2007). The effect of pre-test sensitizing in a digital system on the acquisition of science concepts. In 12th Biennial Conference of the European Association for Research on Learning and Instruction, EARLI 2007, Budapest 27 August - 2 September 2007. [viewed 30 Mar2010, verified 16 Oct 2010] http:/ / www.utwente.nl/elan/onderzoek/ publicaties/elandoc/2007/07-EARLI\%202007_bos,terlouw, pilot.pdf

Crawford, C. (1982). The art of computer game design. [viewed 14 Oct 2005, verified 16 Oct 2010] http: / / directory.vancouver.wsu.edu / people/ sue-peabody/art-computer-game-design 
Creswell, J. W. (1998). Qualitative inquiry and research design: Choosing among five traditions. Thousand Oaks, London, New Delhi: Sage Publications, Inc.

Dochy, F., Segers, M. \& Buehl, M. M. (1999). The relation between assessment practices and outcomes of studies: The case of research on prior knowledge. Review of Educational Research, 69(2), 145.

Engeström, Y. (1987). Learning by expanding: An activity-theoretical approach to developmental research. Helsinki: Orienta-Konsultit.

Engeström, Y. (2000). Activity theory as a framework for analyzing and redesigning work. Ergonomics, 43(7), 960-974.

Engeström, Y. (2001). Expansive learning at work: Toward an activity theoretical reconceptualization. Journal of Education and Work, 14(1), 133-156.

Foko, T. \& Amory, A. (2008). Social constructivism in games based learning in the South African context. In World Conference on Educational Multimedia, Hypermedia and Telecommunications 2008 (pp. 5757-5764). Vienna, Austria: AACE.

Gee, J. (2003). What video games have to teach us about learning and literacy. New York: Palgrave Macmillan.

Gunter, G., Kenny, R. \& Vick, E. (2008). Taking educational games seriously: Using the RETAIN model to design endogenous fantasy into standalone educational games. Educational Technology Research E Development, 56(5/6), 511-537.

Hardman, J. (2005). Activity theory as a framework for understanding teachers' perceptions of computer usage at a primary school level in South Africa. South African Journal of Education, 25(4), 258.

Heck, R. H. (2006). Conceptualizing and conducting meaningful research studies in education. In C. Conrad \& R. Serlin (Eds.), The Sage handbook for research in education: Engaging ideas and enriching inquiry (pp. 373-392). Thousand Oaks, London, New Delhi: Sage Publications, Inc.

Henning, E., Van Rensburg, W. \& Smit, B. (2004). Finding your way in qualitative research. Pretoria: Van Schaik Publishers.

Issroff, K. \& Scanlon, E. (2002). Using technology in higher education: An activity theory perspective. Journal of Computer Assisted Learning, 18(1), 77-83.

Jenlink, P. M. (2001). Activity theory and the design of educational systems: Examining the mediational importance of conversation. Systems Research and Behavioral Science, 18(4), 345359.

Jonassen, D. H. \& Reeves, T. C. (1996). Learning with technology: Using computers as cognitive tools. In D. H. Jonassen (Ed.), Handbook of research on educational communications and technology (pp. 693-719). New York: Macmillan.

Jonassen, D. H., \& Rohrer-Murphy, L. (1999). Activity theory as a framework for designing constructivist learning environments. Educational Technology Research E Development, 47(1), 61-79.

Kaptelinin, V. (2005). The object of activity: Making sense of the sense-maker. Mind, Culture, and Activity, 12(1), 4-18.

Ke, F. (2008a). A qualitative meta-analysis of computer games as learning tools. In R. Ferdig (Ed.), Handbook of research on effective electronic gaming in education (Vols. 1-3, Vol. 1, pp. 1-32). IGI Global.

Ke, F. (2008b). A case study of computer gaming for math: Engaged learning from gameplay? Computers $\mathcal{E}$ Education, 51(4), 1609-1620. 
Kebritchi, M. \& Hirumi, A. (2008). Examining the pedagogical foundations of modern educational computer games. Computers E Education, 51(4), 1729-1743.

Kiili, K. (2008). Teacher's role in media detective game: Communication through non-player game characters. In World Conference on Educational Multimedia, Hypermedia and Telecommunications (pp. 5248-5255). Chesapeake, VA: AACE.

Kim, B., Park, P. \& Baek, Y. (2009). Not just fun, but serious strategies: Using meta-cognitive strategies in game-based learning. Computers \& Education, 52(4), 800-810.

Lana, R. E. (1969/2009). Pretest sensitization. In Artifacts in behavioral research: Robert Rosenthal and Ralph L. Rosnow's classic books (pp. 93-109). New York: Oxford University Press.

Leont'ev, A. N. (1978). Activity, personality, and consciousness. Englewoods Cliffs: Prentice-Hall.

Lim, C. P. (2002). A theoretical framework for the study of ICT in schools: A proposal. British Journal of Educational Technology, 33(4), 411-21.

Merriam, S. B. (2002). Qualitative research in practice: Examples for discussion and analysis. San Fransisco: Jossey-Bass.

Nardi, B. A. (2005). Objects of desire: Power and Passion in collaborative activity. Mind, Culture, and Activity, 12(1), 37-51.

Papastergiou, M. (2009). Digital game-based learning in high school computer science education: Impact on educational effectiveness and student motivation. Computers $\mathcal{E}$ Education, 52(1), 112.

Piaget, J. (1977). The development of thought: Equilibration of cognitive structures. Viking Press.

Prensky, M. (2005). In educational games, complexity matters. Mini-games are trivial - but "complex" games are not. An important way for teachers, parents and others to look at educational computer and video games. [viewed 15 Aug 2005, verified 16 Oct 2010] http:/ / www.marcprensky.com/writing/Prensky-Complexity_Matters.pdf

Puustinen, M., Baker, M. \& Lund, K. (2006). GESTALT: a framework for redesign of educational software. Journal of Computer Assisted Learning, 22(1), 34.

Quinn, C. (2005). Engaging learning. Designing e-learning simulation games. San Francisco: Pfeiffer, John Wiley \& Sons, Inc.

Rieber, L. (1995). A historical review of visualisation in human cognition. Educational Technology, Research \& Development, 43, 45-56.

Rieber, L. (1996). Seriously considering play: Designing interactive learning environments based on the blending of microworlds, simulations and games. Educational Technology Research $\mathcal{E}$ Development, 44(1), 43-58.

Robbins, J. (2005). Contexts, collaboration, and cultural tools: A sociocultural perspective on researching children's thinking. Contemporary Issues in Early Childhood, 6(2), 140-149.

Robertson, J. \& Howells, C. (2008). Computer game design: Opportunities for successful learning. Computers $\mathcal{E}$ Education, 50(2), 559-578.

Rollings, A. \& Adams, E. (2003). Andrew Rollings and Ernest Adams on game design. Indianapolis: New Riders Publishing.

Roth, W. M. \& Lee, Y. J. (2007). "Vygotsky's neglected legacy": Cultural-historical activity theory. Review of Educational Research, 77(2), 186-232.

Scanlon, E. \& Issroff, K. (2005). Activity theory and higher education: Evaluating learning technologies. Journal of Computer Assisted Learning, 21(6), 430-439. 
Seagram, R. (2005). Use of constructivism in the development and evaluation of an educational game environment. PhD thesis, University of KwaZulu-Natal, South Africa.

http: / / researchspace.ukzn.ac.za/xmlui/ handle/10413/488

Seagram, R. \& Amory, A. (2006). An assessment of learning through the use of a constructivist learning environment. In E. Pearson \& P. Bohman (Eds.), World Conference on Educational Multimedia, Hypermedia and Telecommunications 2006 (pp. 2165-2172). AACE.

Shaffer, D. W. (2005). Epistemic games. Innovate, 1(6). [verified 16 Oct 2010] http: / / innovateonline.info/pdf/vol1_issue6/Epistemic_Games.pdf

Shaffer, D. W. \& Clinton, K. A. (2006). Toolforthoughts: Reexamining thinking in the digital age. Mind, Culture, and Activity, 13(4), 283-300. [verified 16 Oct 2010] http:/ / language.la.psu.edu/ thorne/ShafferClinton2007_MCA.pdf

Smeets, E. (2005). Does ICT contribute to powerful learning environments in primary education? Computers \& Education, 44, 343-355.

Squire, K. (2008). Open-ended video games: A model for developing learning for the interactive age. In K. Salem (Ed.), The ecology of games: Connecting youth, games, and learning. The John D. and Catherine T. MacArthur Foundation Series on Digital Media and Learning (pp. 167-198). Cambridge, MA: The MIT Press.

Squire, K. D., DeVane, B. \& Durga, S. (2008). Designing centers of expertise for academic learning through vdeo games. Theory Into Practice, 47(3), 240-251.

Stetsenko, A. (2005). Activity as object-related: Resolving the dichotomy of individual and collective planes of activity. Mind, Culture, and Activity, 12(1), 70-88.

Stevenson, J. (2004). Developing technological knowledge. International Journal of Technology and Design Education, 14(1), 5-19.

Verenikina, I., Herrington, J., Peterson, R. \& Mantei, J. (2008). The affordances and limitations of computers for play in early childhood. In World Conference on Educational Multimedia, Hypermedia and Telecommunications (pp. 3091-3100). Chesapeake, VA: AACE.

Vygotsky, L. (1933). Mind in society. The development of higher psychological processes. Cambridge, MA: Harvard University Press.

Waraich, A. \& Brna, P. (2008). A narrative centred informant design approach for interactive learning environments. International Journal of Continuing Engineering Education and Life Long Learning, 18(2), 181-196.

Professor Alan Amory

Department of Mathematics, Science, Technology and Computer Education

Faculty of Education, University of Johannesburg

Auckland Park 2006, Johannesburg, South Africa

Email: aamory@uj.ac.za 